Nadezhda Nikolova

Institute for Bulgarian Language „Prof. L. Andreychin“ - BAS

nvnikolova@abv.bg

\title{
CURRENT ASPECTS OF SOCIO-CULTURAL COMMUNICATION
}

The development of new socio-cultural relations from the second half of the twentieth century and the beginning of the 21st century led to fundamental changes in the information and communication processes. This is due to the introduction of fundamentally new information and communication technologies in the sphere of human interaction and the development of new metalanguages of culture [Савруцкая 2012: 132].

This article aims at discussing the concept of socio-cultural communication, its characteristic features and functions. Special attention is dedicated to the contemporary approaches and the description of socio-cultural communication, systematization of concepts, theories and scientific research. To determine the features of socio-cultural communication, one has to specify the characteristics of interaction of subjects in the communicative process.

Socio-cultural communication is one of the important phenomena of the contemporary information society, which influences the development of the social relations and processes on a national and an international scale.

In the dynamic and diverse contemporary world, social relations are accompanied by communicative relationships, in which the processes of social communication begin to develop. The interaction between culture and communication is largely determined by the intercultural processes that take place in the cultural systems, by way of interaction between major cultural spheres - religion, philosophy, science, politics, education, technology and technology [Шопова 2005: 2]. These socio-communicative processes, in essence, correspond to the contemporary state of globalization. Moreover, globalization and the latest information technologies transform internal social relations and public control. In turn, they require high efficiency and redundancy in the use of all resources, especially socio-cultural [Сачев, Денчев 2010: 69].

The means of mass communication influence both the socio-political and the cultural-ideological activities of social life. These circumstances generate 
conditions for the emergence of processes leading to an extended framework for the development of culture, the processes of cultural interaction and mutual penetration. Human cultural space projects the means of mass communication - television, radio and the Internet, which satisfy the cultural needs of contemporary humanity. Socio-cultural communication is embedded in the fabric of today's information society, its economy, politics and culture; it encompasses international, intergroup and interpersonal relations. This is why the subject of socio-cultural communication, which occupies a central place in the contemporary social, political and cultural life, is one of the most debated issues of the $21 \mathrm{st}$ century. The necessity of studying socio-cultural communication increases every year with the contemporary transformation of society, which seeks to form its own socio-cultural identity and social organization. This is due to the integrated cultural processes that operate in society. The cultural component of the integration process is a necessary minimum, capable of uniting and strengthening contemporary European thinking.

Socio-cultural communication is the subject of extensive research works by Bulgarian and foreign scholars such as M. Videnov, Kr. Aleksova, K. Isa, T. Shopova, Y. Roth, M. Popova, M. Bachtin, M. Heidegger, H. Gadamer, N. Luman, Yu Habermas, A. Kroeber, B. Markov, A. Vejbitska and others.

The notion of "socio-cultural communication" has no uniform definition, and there are many interpretations of the concept that are based on different methodological paradigms. Most commonly the term "socio-cultural communication" is defined as a set of transferred means of social information that forms the basis for the development of an "information society.

Svetlana Domnich points out:

That the concept of socio-cultural communication acquires a new meaning because the processes of communication take place in the context of a particular culture and are the internal mechanism of its implementation where it is accepted to speak of social and cultural communication. This allows for the formation of social connections, joint controlling vital functions of the people, transfer of social experience, understanding between people [Домнич 2014a: 123].

According to Alfred Kröber, "socio-cultural communication is a set of processes of social interaction in which there is an exchange of information through symbolic systems adopted in culture and the means of their use" [Kröber 1997: 724] This definition is in agreement with the perspective of "Culture. XX century. Encyclopedia“, where it is state d that socio-cultural communication is the interaction between the participants (individuals, groups, organizations, etc.) for the transfer and exchange of information, using the adopted sign language system, methods and means for their use" [вж. Левит, С. и др. 1998].

This terminological definition determines more precisely the specifics of socio-cultural communication as it reflects the temporal slot between the subjects of the intercultural dialogue, socio-cultural activity, dissemination and exchange of information derived from certain cultural systems of signs. 
Academic literature notes that socio-cultural communication is a systemic phenomenon, including: cultural subjects (individuals, groups of people, organizations, etc.); means of social and cultural communication (verbal and non-verbal means of communication, media, material and spiritual values, etc.); the goal of social and cultural communication (mutual understanding, agreement and joint efforts, implementation of socio-cultural values, motivation, incentives, regulation of reality); socio-cultural communication system of actions (information retrieval, explanation, communication, persuasion, proposal, coordination, search, processing, coding, etc.); the result of socio-cultural communication (establishment of agreement, partial agreement, complication of the situation); objects of social and cultural communication (individual individuals, groups, institutions, society, communities, organizations of people, etc.) [Домнич 2014a: 126].

The communication system operates on two levels: horizontal and vertical. On the horizontal level, a specific link is established between the elements of the communication system and the vertical level reflects elements of connection with the source of its existence, information.

A peculiar feature of socio-cultural communication is the clear hierarchy in its structure, each element (means of communication) goes attached to a strictly defined function that performs the common task of transferring cultural information in a certain form.

These basic elements of the system include: the message and the text (cultural forms of an object, phenomenon and process) as well as a specialized cultural and semantic subsystem (knowledge or activity in terms of its information aspect); a local cultural and semantic system (ethnic culture, national language, for instance); and a worldwide semantic system (ethnically specialized languages).

It is important to note that socio-cultural communication in itself is a means of applying the socio-cultural interaction between cultural subjects and their collectives. We accept that socio-cultural communication is a process of interaction between the subjects of socio-cultural activity with a view to transferring or exchanging information. The subject of socio-cultural communication can be individuals, as well as groups, organizations, communities, social institutions. This process is carried out through the presently discussed systems of languages, techniques and means for their use. Socio-cultural communication acts as one of the main mechanisms and is an integral part of the socio-cultural development, providing the opportunity to form cultural ties within individual cultures. In a sense, any cultural action can be regarded as communicative because it contains and expresses certain information. With this approach, culture is regarded as a chain of communicative interactions of different structures. It is, however, legitimate to delimit socio-cultural communication only through such actions that have a communicative meaning, i.e. that transmit information and pursue adequate goals through sign systems.

Socio-cultural communication has four major manifestations:

1. Being innovative, expressed in the participation of cultural subjects in new forms of knowledge and experience; 
2. Direction-giving, helping the subjects of the culture locate themselves in the surrounding settings;

3. Stimulating, i.e. having impact on the activity of cultural subjects, making their potential subject to objective assessment;

4. Correlative, i.e. helping to clarify certain parameters of cultural activities, detailing and specifying particular aspects of knowledge, orientation and incentives.

The main content of socio-cultural communication is a message or a text. Obviously, each cultural subject possessing symbolic properties is a text of culture. This means that a given cultural contextprovides means of communicative interaction as an entire system or byeach one of its individual constituent components.

Like any phenomenon within a system, socio-cultural communication is an important hierarchical structure, in which each communication medium performs a well-defined function, subject to the common goal of cultural information exchange. Key elements include communication, text, a special cultural and semantic subsystem (a branch of knowledge or activities in its information aspect), a local cultural and semantic system (a separate culture, a national language), a global semantic system (different ethnically diversified languages).

Socio-cultural communication, in which the interaction of cultures is a complex and very controversial process, has undergone different stages of development. The nature of intercultural interaction is particularly important today with the rapid development of IT technologies which facilitate the process of global communication and inclusion of the majority of the existing ethnocultural formations.

Considering the experience of the past, when peoples and cultures have disappeared from the face of the earth, the ability of peaceful coexistence of different cultural traditions against suppression, forced assimilation and discrimination, turns out to be a matter of utmost importance. The idea of a dialogue between cultures as a guarantee of peaceful and equal development is presented for the first time by Russian formalist Bakhtin. It formed part of the thinker's views in the later period of his academic quests under O. Spengler's influence. According to Spengler, the isolation of cultures leads to the unawareness of foreign cultural phenomena. For Bakhtin, who compares intercultural dialogue to a dialogue between individuals, diverse cultures do not pose an obstacle to "dialogue", mutual acquaintance and interaction. In his view, contemporary cultures should also be included in the process of "interactive interaction", [Домнич 2014a: 140].

"The Dialogue between Cultures" is not a rigorous scholarly concept: the panorama of contemporary world culture is an alloy of many interacting cultural entities, all of which are original and must coexist in a peaceful meaningful dialogue, by making contact at all means through listening to "the interlocutor" to meet their needs and demands. In this sense, "dialogue" as a means of cultural communication implies the approximation of the interacting agents of the cultural process [Домнич 2014a: 140]. 
A well-performed communication function is a prerequisite for creating a basis for understanding between social actors, between organizations and their audiences, between representatives of different social groups and individuals. On this basis, there are many free associations between individuals that help to form sustainable social groups ranging from interest groups to political parties. The interaction of these groups regulates complex structural interests, moral values and presents their appearance in various forms of public communication.

An important aspect of the contemporary society is the dynamic development of high-tech information communication. The new means of acquiring knowledge and information increasingly tend to become a major asset in public awareness.

Successful socio-cultural communication in society depends on the following factors: the role of communicative strategies for mitigating public conflicts; a communicative mechanism for forming positive attitudes of public opinion; successful public communication between political and public figures; ethics in public communication; changing speech patterns of behavior; the role of liaising with society in forming civil liability; the role of mass media, etc.

The contemporary state of Bulgarian society places the government cultural policy on new democratic principles. It is necessary to coordinate the development of interrelations between centers and regions, interregional interaction, dialogue with society on cultural policy issues, cultural stimulation, as broad access and citizen participation in cultural life is expanding.

The development of social relations is premised upon the close relationships in communication and the inextricable connection between individuals, peoples, societies which underscore the development of the processes within social communication.

Obviously, successful and effective contacts with representatives of other cultures are impossible without the practical skills of socio-cultural communication. To solve this problem we need to develop the ability to properly interpret specific manifestations of communicative behavior in different cultures and therefore to form practical skills. In connection with the expansion of intercultural professional contacts, the need for a society of specialists in different fields increases. Socio-cultural communication allows the realization of successful intercultural interaction, which includes absorption of professionally relevant concepts, determines the specifics of social and business behavior, itself determined by the influence of historical traditions and customs, way of life, etc. Knowledge of aforeign language and its linguistic specifics creates a broad context of intercultural dialogue, effective business communication and professional cooperation.

Contemporary communities are characterized by a constant acceleration and globalization of communications. The quantity and quality of sociocultural communication is steadily rising, the number of people involved in the process increases, the links between the various means of communication are growing alongside the communication network whose expansion reaches global dimensions. Socio-cultural communication opens up new opportunities for 
growth, relieves people of the old constraints of social control and performance systems, establishes a new individual ground for development, relates to the study of the behavior, connections and interactions of large social groups on the scale of the whole society and the world. Socio-cultural communication is the result of information exchange between people using a specific semantic and symbolic system created in the process of development of mankind and it is always in a process of actualization.

EU enlargement, the increased mobility and the need for citizens to understand the rapidly changing and strongly interlinked context - and to act accordingly - put Bulgaria in front of the new challenges. Dialogue between cultures, linguistic diversity and the common experiences of cultural diversity and traditions are an important factor for encouraging and implementing innovative and creative ideas in the Bulgarian context.

\section{Bibliography}

Вежбицкая А. (1996), Язык. Культура. Познание, Издательство „Русские словари”, Москва.

Домнич С. (2014a), Социокультурная коммуникация в некласической парадигме: философскоантропологические аспектыl, „Rocznik Instytutu Polsko-Rosyjskiego”, бp. 1, (6), c. 121-142.

Домнич С. (2014б), Коммуникация в социокультурном пространстве: Философскоантропологические интерпретации, „Гуманітарний часопис”, бр. 1, с. 70-82.

Ионин Л.Г. (1995), Основания соииокультурного анализа. Учебное пособие, Изд-во РГГУ, Москва.

Каптерев А. (2004), Информатизачия сочиокультурного пространства, Москва.

Конецкая В. (1997), Социология коммуникации, Москва.

Крёбер А. (1997), Конфигурации развития культуры, Санкт-Петербург.

Левит, С. и др. (1998), Культурология. ХХ век. Энциклопедия, Университетская книга „Алетейя”, т. 1. СПб.

Моль А. (1979), Социодинамика культуры, Москва.

Почепцов Г. (2003), Коммуникативные технологии ХХ века, Москва.

Савруцкая Е. (2012), Проблемы коммуникации в контексте социокультурной реальности информационного общества, „Вестник Нижегородского университета. Им. Н.И. Лобаческого", т. 1 (3), с. 132-137.

Сачев, Денчев (2010), Паметници на културата и историята: Теоретико-методологични и информационни проблеми, Издателство „За буквите, О писменехъ“, Изток-Запад, София.

Шопова Т. (2005), Нови технологии, нови комуникационни възможности, „Научно-изследователско електронно списание «Известия по история»", бр. 3.

Becker, S.L. (1983), Discovering Mass Communication, Scott, Foresman and Company Glenview, Illinois.

Dahl, S (2004), Intercultural Research, [in:] The Current State of Knowledge, University Business School Discussion Paper, Middlesex.

Gudykunst, W.B. (2000), Methodological Issues in Conducting Theory-Based Cross-Cultural Research, [in:] Spencer-Oatey (ed.), p. 293-315.

McQuail, D.(1989), Mass Communication Theory. AnIntroduction, Sage Publications Ltd, London.

Wilson, S. le Roy (1992), Mass Media/Mass Culture. An Introduction, McGraw-Hill, Inc., New York. 
Nadezhda Nikolova

\section{АКТУАЛНИ АСПЕКТИ НА СОЦИОКУЛТУРНАТА КОМУНИКАЦИЯ}

(Резюме)

В динамичния съвременен свят обществените отношения се съпровождат от отношения на общуване, при което се развиват процесите на социалната комуникация. Средствата за масова комуникация оказват влияние както на социално-политическата, така и на културно-идеологическата дейност от живота на обществото.

Модерното комуникационно общество се характеризира с постоянното ускоряване и глобализация на социокултурната комуникация. Непрекъснато се увеличава степента и качеството на този тип взаимодействия, нараства броят на хората, които участват в комуникационните процеси. Връзките между отделните форми на комуникация стават все по-обхватни и комуникационната мрежа расте до такава степен, че придобива глобални измерения. Социокултурната комуникация създава нова сфера за развитие, свързана е с изучаване на поведението, връзките и взаимодействията сред големите социални групи.

Key words: комуникация, култура, социокултурна комуникация, функции, лингвистични особености. 